\title{
PELAKSANAAN PENGIKATAN JUAL BELI RUMAH DENGAN SISTEM PESAN BANGUN (AL-'URBÛN) PADA PT. PRATAMA GRIYA MAKMUR KABUPATEN PASAMAN BARAT
}

\author{
Baldi Pramana \\ Universitas Andalas, baldi_pramana@gmail.com \\ Busyra Azheri \\ Universitas Andalas,ba1969bd@gmail.com
}

\begin{abstract}
The home marketing strategy that is currently being used is home sales in the form of images (pre-project selling). The transaction is set out in the form of Bonds for Sale and Purchase (PJB) which in practice raises various problems, both in terms of PJB content and the quality of work results. PJB for developers is often used to break the law and legislation such as by disguising the actions of company directors for and on behalf of themselves, consumers are required to pay excess land prices that were not previously agreed and thought of, down payments that originally increased from the price offered, the construction of the house is not in accordance with the specifications and general standards, the delay in the submission of the certificate, the fasum problem, which should be the responsibility of the developer. From the description above, the problem examined was how to implement the sale and purchase of houses through the built-in message system at PT. Pratama Griya Makmur Regency of West Pasaman and how to protect the rights of consumers. This study uses an empirical juridical approach. The results of the study show the implementation and legal protection for consumers in buying and selling houses through a built-in message system at PT. Pratama Griya Makmur, West Pasaman Regency has been carried out by breaking the rules, namely parties representing companies in making PJB are directors, acting for and on behalf of themselves, in PJB the building specifications are not included, sanctions for cancellation of agreements, rights and obligations of the parties are not included implicitly.
\end{abstract}

Keywords: Implementation, Engagement, Sale and Purchase, Pre-Project Selling, Pasaman Barat.

\begin{abstract}
Abstrak
Strategi pemasaran rumah yang saat ini sedang banyak digunakan adalah penjualan rumah dalam bentuk gambar (pre project selling). Transaksi tersebut dituangkan dalam bentuk Pengikatan Jual Beli (PJB) yang pada prakteknya menimbulkan berbagai masalah, baik ditinjau dari isi PJB maupun kualitas hasil pekerjaan. PJB bagi pengembang sering digunakan untuk menerobos aturan bukum dan perundangundangan seperti dengan cara penyamaran tindakan direktur perusabaan untuk dan atas nama pribadi, konsumen diwajibkan membayar harga kelebihan tanah yang sebelumnya tidak diperjanjikan dan terpikirkan, uang tanda jadi (down payment) yang semula bertambah besar dari harga yang ditawarkan, konstruksi rumah tidak sesuai dengan spesifikasi dan standar umum, keterlambatan penyerahan sertifikat, masalah fasum, yang seharusnya hal ini menjadi tanggung jawab pengembang. Dari uraian diatas permsalahan yang diteliti adalah bagaimana pelaksanaan pengikatan jual beli rumah melahi sistem pesan bangun pada PT. Pratama Griya Makmur Kabupaten Pasaman Barat dan bagaiaman perlindungan bak kosmumen. Penelitian ini menggunakan pendekatan yuridis empiris. Hasil penelitian menunjukkan pelaksanaan dan perlindungan bukum bagi konsumen dalam jual beli rumah melalui sistem pesan bangun pada PT. Pratama Griya Makmur Kabupaten Pasaman Barat selama ini dilakukan dengan menerobos aturan, yaitu pibak yang mewakili perusahaan dalam membuat PJB adalah pribadi direktur, bertindak. untuk dan atas nama pribadi, didalam PJB sepesifikasi bangunan tidak dicantumkan, sanksi pembatalan perjanjian, hak dan kewajiban para pibak tidak dicantumkan secara implisit.
\end{abstract}

Kata Kunci: Pelaksanaan, Pengikatan, Jual-Beli, Pesan Bangun, Pasaman Barat. 


\section{PENDAHULUAN}

Keberadaan rumah sebagai suatu hak rakyat atas tempat tinggal juga telah diatur dalam Pasal 28 h Undang Undang Dasar 1945 (UUD NRI 1945) ayat (1) menyebutkan bahwa setiap orang berhak hidup sejahtera lahir dan batin. Bertempat tinggal, dan mendapatkan lingkungan hidup yang baik dan sehat serta berhak memperoleh pelayanan kesehatan."

$$
\text { Pengaturan dan pengertian }
$$
perumahan lebih jauh di jabarkan dalam Pasal 1 ayat (1) Undang-Undang Nomor 1 Tahun 2011 tentang Perumahaan dan Kawasan Pemukiman menjelaskan perumahan adalah kumpulan rumah sebagai bagian dari pemukiman, baik perkotaan ataupun perdesaan, yang dilengkapi dengan prasarana, sarana, dan utilitas umum sebagai hasil upaya pemenuhan rumah yang layak huni. ${ }^{1}$ Adapun program perumahan yang sedang giat dilakukan oleh pengembang di Provinsi Sumater Barat adalah program sejuta rumah sejak taun $2016{ }^{2}$

Berdasarkan program sejuta rumah tahun 2016 pada Provinsi Sumatera Barat, di Kabupaten Pasaman Barat para pengembang memanfaatkan peluang dengan melaksanakan pembangunan perumahan rakyat, yaitu pengadaan rumah oleh pengembang dengan cara penjualan rumah sebelum dibangun dimana properti masih dalam bentuk gambar (pre project selling).

Kabupaten Pasaman Barat sebagai salah satu kabupaten termuda di Provinsi Sumatera Barat pada tahun 2015 memiliki penduduk sebanyak 410.307 jiwa. $^{3}$ Saat ini banyak para pengembang yang mulai membangun dan memasarkan rumah dengan

\footnotetext{
${ }^{1}$ Sri Soedewi Masjchun Sofwan, Hukum Bangunan, Perjanjian Pemborongan Bangunan, Yogyakarta: Liberty, 1982, 103.

2 http:kulliaharsitektblogspot.com, diakses pada hari Selasa tanggal 20 Februari 2018.

${ }^{3}$ https://pasamanbaratkab.bps.go.id, diakses pada hari Rabu tanggal 13 Juni 2018.
}

berbagai variasi atau model dan harga di antaranya adalah PT. Pratama Griya Makmur menawarkan rumah melalui brosur, spanduk yang dipasang di berbagai tempat disekitar lokasi serta melalui ouletnya. Timbulnya masalah hukum antara konsumen dengan pengembang baik ditinjau dari isi PJB dan gambar rumah dalam brosur/teknis bangunan dengan pelaksanaan pembangunan yang diterima konsumen saat menepati rumah seperti direktur perusahaan bertindak atas nama pribadi, konsumen diwajibkan membayar harga kelebihan tanah yang sebelumnya tidak terpikirkan, uang tanda jadi (down payment) yang semula bertambah besar dari harga yang ditawarkan sebelumnya pada browsur, konstruksi rumah tidak sesuai dengan spesifikasi dan standar umum, keterlambatan penyerahan sertifikat, masalah fasum, dan sebagainya.

Untuk itu, penelitian ini mengkaji bagaimana pelaksanaan pengikatan jual beli rumah melalui sistem pesan bangun pada PT. Pratama Griya Makmur Kabupaten Pasaman Barat dan bagaiaman perlindungan hak kosmumen.

\section{METODE PENELITIAN}

Untuk memperoleh data bahan yang diperlukan dalam penelelitian ini, maka penulis melakukan peneltian dengan metode yang biasa dan umum digunakan dalam penelitian hukum yaitu dengan mengunakan data yuridis empiris yaitu dengan mengunakan data sekunder dengan melakukan penelitian lapangan dan wawancara atau tanya jawab secara langsung dikaitkan dengan peraturan perundang-undangan dan isi PJB yang disepakati. $^{4}$

\footnotetext{
${ }^{4}$ Amiruddin dan Zaina Asikin, Pengantar Motode Penelitian Hukum, (Jakarta: PT. Raja Grafindo Persada, 2004), 35.
} 


\section{SISTEM "DP" DALAM HUKUM ISLAM}

Down Payment atau Panjar dalam bahasa Arab adalah al-urbûn (العربون) yang Secara bahasa artinya, kata jadi transaksi dalam jual beli. Deskripsi jual beli dengan DP yaitu, sejumlah uang yang dibayarkan di muka oleh seorang pembeli barang kepada si penjual. Bila transaksi itu mereka lanjutkan, maka uang muka itu dimasukkan ke dalam harga pembayaran. Kalau tidak jadi, maka uang yang dibayarkan di muka menjadi milik si penjual.

Secara ringkas, sistem jual beli seperti ini dikenal dalam masyarakat kita dengan pembayaran DP atau uang jadi.

Dalam permasalahan ini, terdapat perbedaan dikalangan para ulama, yang terbagi dalam pendapat.

Pertama, pendapat bahwa jual-beli dengan uang muka (panjar) ini tidak sah. Ini adalah pendapat mayoritas ulama di kalangan Hanafiyyah, Malikiyyah dan Syafi'iyyah. Para ulama berselisih pendapat tentang bolehnya jual beli dengan DP. Imam Malik dan Imam Syafi'i menyatakan ketidaksahannya, karena adanya hadis dan karena terdapat syarat fasad (rusak) dan al-Gharar (spekulasi), Juga, jual-beli seperti ini termasuk dalam kategori memakan harta orang lain dengan cara yang buruk. Yang menjadi argumentasi pendapat ini, di antaranya Hadis Amru bin Syuaib, dari ayahnya, dari kakeknya bahwa ia berkata:

نَهَهَى رَسُولُ اللَّهِ صَلَّى اللَّهُ عَلَيْهِه وَسَلَّمَ عَنْ بَبْعِ الْعُرْبَانِ

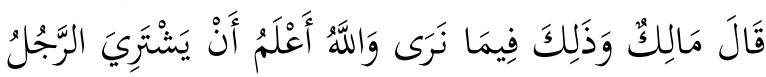

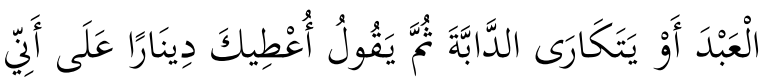

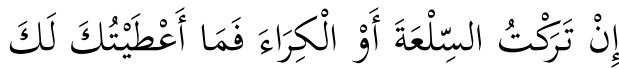

"Rasulullah Shallallabu 'alaibi wa sallam melarang jual beli dengan sistem nang muka. Imam Maalike berkata : "Dan inilah adalab yang kita libat wallahu A'lam- seorang membeli budak atau menyewa hewan kendaraan kemudian berkata, 'Saya berikan kepadamu satu dinar dengan ketentuan apabila saya membatalkan (tidak jadi) membeli atau tidak jadi menyewanya, maka uang yang telah saya berikan itu menjadi milikmu"
Kedua, pendapat yang menyatakan Jual Beli dengan Uang Muka diperbolehkan. Inilah pendapat madzhab Hambaliyyah. Berdasarkan kebolehannya dari Umar bin Khatthab, Ibnu Umar, Sa'id bin Al Musayyib dan Muhammad bin Sirin.

Imam Ahmad bin Hambal cenderung mengambil pendapat yang membolehkannya dan menyatakan. Imam Ahmad berpendapat bahwa beliau tidak mampu menyatakan sesuatu sedangkan ini pendapat Umar bin Khatthab yaitu tentang bolehanya jual-beli dengan uang muka. Imam Ahmad juga melemahkan (men-dhaif-kan) hadis larangan jual-beli yang seperti ini, disebabkan terputus. Argumentasi pendapat yang membolehkan ini adalah bukti sejarah bahwa Abdullah bin Umar pernah membelikan sebuah bangunan penjara untuk Umar dari Shafwan bin Umayyah, (dengan ketentuan) Apabila Umar suka. Bila tidak, maka Shafwan berhak mendapatkan uang sekian dan sekian.

Uang muka adalah kompensasi yang diberikan kepada penjual yang menunggu dan menyimpan barang transaksi selama beberapa waktu. Dia tentu saja akan kehilangan sebagian kesempatan berjualan. Dengan demikian, maka tidaklah benar pandangan yang mengatakan, bahwa uang muka telah dijadikan syarat oleh penjual tanpa ada imbalannya.

Syaikh Abdul Aziz bin Baaz, Mantan Katua Dewan Fatwa Kerajaan Arab Saudi pernah ditanya tentang bagaimana hukum melaksanakan jual beli sistem panjar (al-urbun) apabila belum sempurna jual belinya. Bentuknya yaitu, dua orang melakukan transaksi jual beli, Apabila jual beli sempurna maka pembeli melunasi nilai pembayarannya dan bila pembeli batal melakukan pembelian, maka si penjual mengambil DP (uang muka) tersebut dan tidak mengembalikannya kepada pembeli. Pertanyaan ini dijawab bahwa tidak mengapa mengambil DP (uang muka) tersebut, menurut pendapat yang rajih dari dua 
pendapat ulama. Apabila penjual dan pembeli telah sepakat untuk itu dan jual belinya tidak dilanjutkan (tidak disempurnakan).

Kemudian tentang bolehkah seorang penjual mengambil uang muka dari pembeli? Dan jika pembeli batal membelinya atau mengembalikan pembeliannya, apakah secara hukum syari'at si penjual berhak mengambil uang muka tersebut untuk dirinya tanpa mengembalikannya kepada si pembeli? Beliau menjawab bahwa apabila keadaannya demikian, maka dibolehkan bagi si penjual untuk memiliki uang muka tersebut untuk dirinya dan tidak mengembalikannya kepada pembeli apabila keduanya telah sepakat untuk itu.

\section{DASAR HUKUM PENGIKATAN JUAL BELI}

Ada beberapa sumber hukum yang dapat dijadikan dasar untuk mengetahui sejauh mana penerapan hukum terhadap konsumen dengan pengembang dalam jual beli rumah melalui sistem pesan bangun, antara lain;

\section{Undang-Undang Nomor 30 Tabun 2004 Tentang} Jabatan Notaris

Dalam Pasal 1 angka 1 UUJN Notaris adalah Pejabat Umum yang berwenang untuk membuat akta autentik dan memiliki kewenangan lainnya sebagaimana dimaksud dalam undang-undang ini atau berdasarkan undang-undang lainnya. Berdasarkan ketentuan Pasal 15 ayat 1 UndangUndang Jabatan Notaris menyebutkan Notaris berwenang membuat akta otentik mengenai semua perbuatan, perjanjian dan penetapan yang diharuskan oleh peraturan perundangundangan dan / atau yang dikehendaki oleh yang berkepentingan untuk dinyatakan dalam akta otentik.

Notaris mempunyai kewenangan untuk membuat akta otentik mengenai semua perbuatan, perjanjian dan penerapannya yang diperintahkan oleh peraturan umum atau diminta oleh yang bersangkutan. Notaris menghadapi masalah hukum kongkrit atau peristiwa yang diajukan oleh klien merupakan tugas Notaris, disinilah Notaris melakukan penemuan hukum. ${ }^{5}$ Berdasarkan pendapat Sudikno Mertokusumo, Notaris pembuat akta PJB dan menurut penulis atas dasar ketentuan Pasal 1313 KUHPerdata Jo Pasal 15 ayat 1 dan ayat 2 huruf $f$ Notaris berwenang membuat PJB.

\section{Undang-Undang Nomor 8 Tabun 1999 Tentang Perlindungan Konsumen (UU-PK) \\ Dalam penerapan perlindungan hukum} dalam jual beli rumah melalui sistem pesan bangun, Pengembang sebagai penyelenggara perumahan dan pemukiman berkewajiban untuk melakukan upaya perlindungan terhadap konsumen, hal ini disebabkan karena hukum perjanjian jual beli rumah terbentuk berdasarkan perjanjian diantara kedua belah pihak sehingga adapun hak dan kewajiban yang timbul berdasarkan perjanjian tersebut harus dapat dipenuhi dan terpenuhi (sejajar) dan itu diatur dalam undang-undang ini.

\section{Undang-Undang Nomor 1 Tabun 2011 Tentang Perumahan dan Kawasan Pemukiman.}

Guna memastikan terjaminnya hak hak warga negara dalam penyelenggaraan perumahan dan pemukiman dari pengembang maka dalam Pasal 134 Undang-Undang Nomor 1 Tahun 2011 tentang Perumahan dan Kawasan Pemukiman telah menetapkan larangan untuk pengembang, yaitu setiap orang dilarang menyelenggarakan pembangunan perumahan yang tidak membangun perumahan sesuai dengan kriteria, spesifikasi, persyatan, prasarana, sarana, dan utilitas umum yang diperjanjikan.

Keputusan Menteri Negara Perumahan Rakyat

5 Sudikno Mertokusumo, 2004, artikel “Arti Penemuan Hukum", Majalah Renvoi, edisi tahun 1, No 12, 48-49. 
Nomor 09/KPTS/M/1995 Tentang Pedoman

Pengikatan Jual Beli Rumah.

Menurut Kepmenpera Nomor

09/KPTS/M/1995 tentang Pedoman

Pengikatan Jual Beli memuat beberapa aturan antara pengembang dan konsumen, berupa ${ }^{6}$; Kewajiban pengembang, Jaminan penjual, Kewajiban pembeli, Serah terima bangunan, Penggunaan Bangunan, Pengalihan hak, Ketentuan pembatal pengikatan, Akta jual beli, dan Penyelesaian perselisihan. Ketentuan Kepmenpera tersebut merupakan kewajiban kedua belah pihak dalam membuat perikatan perjanjian jual beli rumah.

\section{KEDUDUKAN PJB RUMAH MELALUI SITEM PESAN BANGUN}

Sebagaimana disebutkan di atas, bahwa perjanjian perikatan jual beli rumah (PJB) merupakan terobosan hukum yang sudah jamak diperaktekkan oleh Notaris dan para pihak dalam transaksi jual beli rumah.Hal ini dikarenakan tidak semua orang mampu secara materil dan inmateril memenuhi semua ketentuan tentang aturan jual beli rumah dan bangunan, dimana wajib dilakukan dengan tunai. Dalam PJB Harus ditegaskan bahwa pengembang telah memiliki atau menguasai lahan tersebut secara sah dan tidak dalam keadaan dijaminkan. Untuk mengetahui makna dari pelaksanaan hukum PJB bagi para pihak, maka kita harus terlebih dahulu mengetahui pengertian tentang Akta dan Perikatan Jual Bel. Akta dalam bahasa Belanda mempunyai dua arti yaitu Perbuatan (bandeling)/ perbuatan hukum (rechtshandeling) dan Suatu tulisan yang dibuat untuk di pakai/digunakan sebagai bukti perbuatan hukum tersaebut, yaitu berupa tulisan yang di tujukan kepada pembuktian sesuatu. $^{7}$

Berdasarkan hal-hal diatas untuk

\footnotetext{
${ }^{6}$ Kepmenpera Nomor 09/KPTS/M/1995 tentang Pedoman Pengikatan Jual Beli Rumah.

${ }^{7}$ Victor M. Situmorang dan An Cormentyana Sitanggang, Grosse Akta Dalam Pembuktian dan Eksekusi, (Jakarta: Renika Cipta, 1993), 54.
}

menghindari penyelewengan wewenang dari para pihak dikarenakan kedudukan pengembang mempunyai kedudukan yang lebih kuat, maka dalam PJB PT. Pratama Griya Makmur dengan konsumen mecantumkan sebagai hak-hak tanah dan bangunan sebagai berikut ${ }^{8}$;

a. Penjual tidak dapat menyerahkan tanah dan bangunan rumah beserta hak-hak yang melekat padanya, tepat waktu yang diperjanjikan, sedangkan pembeli telah selesai kewajibannya untuk membayar harga tanah dan bangunan tersebut.

b. Penjual menyerahkan tanah dan bangunan rumah yang tidak cocok dengan gambar denah dan spesifikasi teknis bangunan yang telah ditetapkan bersama dan menjadi lampiran dalam Perjanjian Pengikatan Jual Beli Rumah. Apabila dalam keadaan dimaksud dalam hurup a dan $\mathrm{b}$ tersebut terjadi, maka perjanjian jadi batal, penjual wajib mengembalikan uang yang telah diterima, ditambah dengan denda, bunga dan biaya-biaya lainnya kepada konsumen, sesuai dengan ketentuan yang berlaku menurut hukum.

c. Pembeli tidak dapat memenuhi dan atau tidak dapat meneruskan kewajiban untuk membayar harga tanah dan bangunan rumah sesuai dengan yang diperjanjikan.

d. Pembeli menggundurkan diri atau membatalkan transaksi jual beli tanah dan bangunan rumah karena sesuatu sebab atau alasan tertentu. Apabila keadaan yang dimaksud dalam butir c dan d tersebut terjadi, maka perjanjian menjadi batal dan penjual wajib mengembalikan uang yang telah diterimanya setelah dikurangi dengan denda, bunga, dan biaya-biaya lainnya sesuai dengan ketentuan yang berlaku menurut hukum.

\footnotetext{
${ }^{8}$ Nurzal Jefry, SH, Wawancara, pada tanggal 16 September 2018.
} 


\section{PENGIKATAN JUAL BELI RUMAH SEBAGAI ALAT BUKTI}

Pasal 1867 KUHPerdata menyebutkan pembuktian dengan tulisan dilakukan dengan tulisan (akta) otentik maupun dengan tulisantulisan (akta dibawah tangan. Sesuai dengan asas hukum yang berlaku akta otentik mempunyai 3 (tiga) kekuatan pembuktian jika dibandingkan dengan akta dibawah tangan, yaitu; Kekuatan pembuktian lahiriah, Kekuatan pembuktian formal, dan Kekuatan pembuktian materil.

Jadi akta perikatan jual beli yang dibuat dihadapan atau oleh Notaris atas setiap keterangan yang dibenarkan para pihak dapat diartikan memberikan pembuktian yang sempurna sebagai alat bukti karena sesuai dengan syarat-syarat sahnya perjanjian sepanjang tidak dapat dibuktikan sebaliknya berdasarkan putusan pengadilan yang mempunyai kekutan hukum tetap.

\section{LEGALITAS DAN PERSYARATAN KEPEMILIKAN RUMAH PADA PT. PRATAMA GRIYA MAKMUR.}

Perizinan (legalitas) merupakan bentuk dari pengawasan dan perlindungan hukum terhadap masyarakat khusunya konsumen. Pengawasan terbagi kedalam dua bentuk, yaitu pertama pengawasan oleh role of law (perangkat perundang-undangan) atau instansi pemerintah, dan kedua pengawasan dalam kontes internal perusahaan penyelenggara perumahan dalam hal ini mandor lapangan PT. Pratama Griya Makmur. Adapun aturan berkenan mengenai pengawasan pembangunan rumah melalui sistem pesan bangun di PT. Pratama Griya Makmur dapat dilihat dalam Pasal 12 angka 2 Peraturan Menteri Pekerjaan Umum dan Perumahan Rakyat Republik Indonesia Nomor 21/PRT/M/2016 Tentang Kemudahan dan/atau Bantuan Perolehan Rumah Bagi Masyarakat Berpenghasilan Rendah menyebutkan bahwa bank pelaksana bertanggung jawab atas ketepatan sasaran secara legal formal, dan bersedia diaudit oleh aparat pengawasan interen Kementerian Pekerjaan Umum dan Perumahan Rakyat dan/ atau pengawasan eksternal sesuai dengan peraturan perundang-undangan.

Berdasarkan hasil penelitian pembangunan rumah melalui sistem pesan bangun di PT. Pratama Griya Makmur terlihat tanpa ada pengawasan dari badan atau petugas berwenang dari Badan Kementerian Pekerjaan Umum dan Perumahan Rakyat, akan tetapi tanpa pengawasan dari pemerintah secara langsung pengembang berlomba-lomba meningkatkan mutu bangunan rumah agar dapat menarik minat konsumen membeli rumah. PT. Pratama Griya Makmur sebagai penyelenggara perumahan di Kabupaten Pasaman Barat yang pertama sekali terjun dalam jual beli rumah melalui pola pre selling project dimana terlebih dulu konsumen menentukan lokasi, jenis, dan tipe rumah yang dihendakinya, persetujuan atas lokasi, jenis dan tipe rumah ini berkaitan dengan harga rumah. Selanjutnya konsumen di wajibkan untuk membayar uang tanda jadi (booking fee) sebagai jaminan Rp. 2.000 .000 ( dua juta rupiah) baik untuk tipe 36/120 $\mathrm{m}$ dan untuk tipe $45 .{ }^{9}$ Setelah konsumen membayar boxing fee, konsumen diminta membuat skema pelunasan harga rumah, dan perlu dipahami bahwa model pembelian rumah cash atau kredit sangat menentukan jenis dan syarat-syarat atau dokumen yang harus dilengkapi oleh konsumen. Jadi setiap pembelian rumah pada PT. Pratama Griya Makmur konsumen otomatis telah memperoleh perizinan dari instansi terkait dan tidak dibebani dengan kewajiban pengurusan izin-izin oleh pemerintah.

\section{PELAKSANAAN PERLINDUNGAN HUKUM TERHADAP KONSUMEN MELALUI PJB PADA PT. PRATAMA GRIYA MAKMUR.}

Perikatan jual beli sebagai sebuah

\footnotetext{
${ }^{9}$ Ibid.
} 
dokumen hukum dan menjadi rujukan apabila ada sengketa diantara konsumen dengan pengembang pada PT. Pratama Griya Makmur setelah penulis kaitkan dengan penerapan hukum teori perlindungan hukum, teori tanggung jawab hukum dan teori kepastian hukum mengenai pihak yang bertindak mewakili PT. Pratama Griya Makmur dalam PJB yaitu Bapak Nurzal Jefri, SH selaku pribadi dan bukan atas nama direksi. Padahal dalam Pasal 98 ayat (1) Undang Undang Nomor 40 Tahun 2007 tentang Perseroan Terbatas pada pokoknya menyebutkan bahwa kepengurusan perusahaan baik didalam dan diluar pengadilan dilakukan oleh Direksi, selanjutnya Pasal 92 ayat (1) Undang Undang Nomor 40 Tahun 2007 tentang Perseroan Terbatas mengamanahkan kepada Direksi dalam menjalankan tujuan kepengurusan perusahaan untuk kepentingan sesuai maksud dan tujuan perseroan.

Dalam isi PJB yang dibuat antara konsumen dengan PT. Pratama Griya Mandiri direktur bertindak untuk dan atas nama pribadi bukan perorangan hal ini bisa memberikan ketidak pastian dan perlindungan hukum bagi konsumen. Pihak PT. Pratama Griya Makmur bisa saja lepas tangan apabila ada tuntutan hukum mengenai isi perjanjian karena konsumen berjanji dengan pribadi direktur.

Terkait juga dengan masalah kualitas hasil pekerjaan pada tahapan pembangunan rumah walaupun sudah dikerjakan dengan baik, bisa saja dikemudian hari ditemui berbagai kekurangan dan kerusakan pada bangunan. Keadaan tersebut tentu saja tidak dapat merugikan pihak pengembang, konsumen, juga demikian dengan pihak ketiga tidak mau rugi. Hal lain yang terlihat oleh peneliti pada isi PJB yang dibuat antara konsumen dengan pengembang adalah sepesifikasi bangunan dalam isi perjanjian tersebut tidak dicantumkan, hanya tertera pada brosur pengembang/ gambar teknis dan ini bisa di manfaatkan oleh pengembang untuk berkilah apabila terjadi wanprestasi dan pengembang juga bisa mencari keuntungan dari jenis dan spesifikasi teknis. Begitu juga dengan hak dan kewajiban para pihak tidak dicantumkan secara implist dalam klousulklosul PJB, syarat-syarat pelaksanaan dan pembangunan objek jual beli, ketentuan pembatalan perjanjian, sanksi pembatalan perjanjian.

Dalam perakteknya pada PT. Pratama Griya Makmur selain kekurangan yang terjadi akibat kelengahannya, sesuai hasil penelitian di lapangan ditemukan juga kekurangan pekerjaan disebabkan oleh kelalaian pihak ketiga, misalnya kasus yang dialami oleh beberapa konsumen seperti yang telah ditelusuri. Di antaranya;

Tuan Fabmi, (Blok Q/ 11) membeli rumah sesuai PJB pada tanggal $23-07-2015$ (dua puluh tiga juli dua ribu lima belas), pada saat serah terima rumah, yang bersangkutan telah memeriksa seluruh kondisi rumah baik interior dan eksterior dengan hasil baik dan memuaskan. Namun tidak lama setelah rumah ditempati dimana kondisi rumah yang semula baik terutama pondasi rumah pecah, kunsen pintu dan jedela kropos, dinding rumah pecahpecah, begitu juga lantai keramik apabili di injak maka akan berbunyi. ${ }^{10}$ Kondisi yang dialami oleh tuan Fahmi tersebut di sampaikan kepada staf PT. Pratama Griya Makmur agar segera meperbaiki rumah, berdasarkan perjanjian perikatan jual beli konsumen berhak atas pemiliharaan selama 100 (seratus hari) hari, hal ini sesuai dengan isi Kepmenpera 09/Kpts/M/1995 tentang Pedoman Pengikatan Jual Beli Rumah, menegaskan bahwa masa pemiliharaan yang wajib diberikan oleh pengembang kepada konsumen selama 100 (seratus) hari.PT. Pratama Griya Makmur setelah mendengar laporan dari yang bersangkutan dalam jangka waktu 1 (satu)

\footnotetext{
${ }^{10}$ Fahmi, Konsumen Perumahan PT. Pratama Griya Makmur Blok Q 11, Wawancara, pada tanggal 22 Juli 2018 pukul 13: 30-14:30 WIB.
} 
minggu memperbaiki pondasi rumah, menganti kunsen pintu yang rusak, memperbaiki dinding rumah pada titik-titik yang mengalami kerusakan dan lantai keramik rumah. Dalam hal ini pengembang sudah beritikat baik melaksanakan pengikatan jual beli sesuai perjanjian.

Tuan Nofi Hendra (Blok M/ 12) membeli rumah (PPJB) pada tanggal 23 Juli 2015 dan serah terima dilaksanakan pada tanggal 27 Juli 2015. Pada saat itu konsumen telah melakukan pengecekan didalam dan diluar rumah dimana kondisi dalam keadaan baik dan rapi. Tidak cukup lama setelah yang bersangkutan menepati rumah diwaktu musim penghujan melihat rembesan air dari atap rumah membasahi kunsen jendela dan pintu bagian samping dan belakang rumah. ${ }^{11}$ Kejadian yang dialami oleh tuan Nofi Hendri tersebut dialoprkan kepada ke pihak PT. Pratama Griya Makmur, kemudian langsung menindak lanjuti keluhan konsumen dengan melakukan perbaikan kunsen jendala dan pintu rusak itu. Sumber rembesan air dari loteng rumah diperbaiki.

Tuan Eki Kurniawan, SE. (Blok/ J) membeli rumah berdasarkan PPJB pada tanggal 23 Juli 2016, pada saat pihak developer melakukan serah terima rumah yang bersangkutan telah mengajukan komplain disebabkan pondasi galian drainase di halaman romah tidak dibuat sesuai gambar, begitu juga plat jembatan tidak ada, kualitas loteng asal jadi dan perlu perbaikan serta air PDAM sebagaimana perjanjian belum terpasang. Pihak PT. Pratama Griya Makmur berjanji akan menindak lanjuti komplain tersebut dalam jangka waktu 14 (empat belas) hari. Berdasarkan PJB, pihak developer berkewajiban guna memperbaiki loteng dan menyambung airPDAM ke rumah konsumen sehingga pelaksana lapangan menginstruksikan

11 Nofie Hendra, Konumen Perumahan PT. Pratama Griya Makmur Blok Q 13, Wawancara, pada tanggal 22 Juli 2018 pukul 14: 30-15 :00 WIB. tukang untuk memperbaiki loteng rumah.

Bedasarkan uraian-uraian diatas, maka sejauh ini perlindungan konsumen yang terjadi di PT. Pratama Griya Makmur berjalan sesuai dengan hak dan kewajiban yang tertera dalam PJB meskipun menurut analisa hukum penulis ada beberapa peraturan perundang-undangan dan peraturan teknis perumahan lainnya yang di siasati atau diterobos oleh pegembang dan hal ini mengambarkan belum sepenuhnya teori perlindungan hukum, teori kepastian hukum dan teori tanggung jawab terhadap konsumen teruji sepenuhnya.

Respon siap tanggap atas komplain konsumen yang dijalankan oleh PT. Pratama Griya Makmur, menurut penulis dalam rangka memberikan perlindungan, kepastian dan pertanggung jawaban hukum dan prinsip bahwa perjanjian yang dibuat dan disepakati bersama menjadi peraturan bagi kedua belah pihak yang membuatnya. Meskipun terkadang tidak semua komplain konsumen bisa di tindak lanjuti dengan segera tetapi sesuai dengan pasal 7 Hurup a UUPK mengantur kewajiban pengembang untuk beritikat baik dalam melaksanakan kegitan usahanya. PT. Pratama Griya Makmur sudah memberikan itikat baik agar bersedia menindak lanjuti setiap komplain dari konsumen meski tidak semua bentukbentuk komplain di atur dalam PJB tetapi ditindak lanjuti dan sampai dengan saat ini belum pernah terjadi sengketa konsumen dengan PT.Pratama Griya Makmur yang diselesaikan melalui jalur hukum baik didalam dan diluar pengadilan.

\section{KESIMPULAN}

Berdasarkan hasil penelitian dan pembahasan yang telah Penulis uraikan pada bagian sebelumnya, maka dapat disimpulkan bahwa pelaksanaan pengikatan jual beli rumah antara konsumen dengan pengembang melalui sistem pesan bangun yang dibuat dihadapan Notaris diawali dengan adanya persetujuan jual beli rumah antara konsumen dengan 
pengembang, hal ini dikarenakan tidak semua orang mampu secara materil dan inmateril memenuhi semua ketentuan tentang aturan jual beli rumah dan bangunan, dimana wajib dilakukan dengan tunai dan nyata. Guna mengatasi situasi tersebut pengembang dan konsumen sepakat menuangkan kehendak / perbuatan / prestiwa hukum yang bebas kedalam pengikatan jual beli rumah (PJB). Pengikatan jual beli juga menjadi bukti atau dasar hukum bagi konsumen untuk meminta hak-haknya dipenuhi oleh pengembang apabila dirugikan. Adapun dasar kekutan hukum pengikatan jual beli rumah yang dibuat dihadapn Notaris adalah Undang-Undang Nomor 30 Tahun 2004 Tentang Jabatan Notaris, Undang-Undang nomor 8 Tahun 1999 tentang Perlindungan Konsumen, yang diundangkan pada tanggal 20 April 1999 dalam lembaran Negara Republik Indonesia Tahun 1999 Nomor 42, berlaku efektif pada tanggal 20 April 2000. Selain itu, pengembang dalam membuat pengikatan jual beli berpedoman juga dengan Undang-Undang Nomor 1 Tahun 2011 tentang Perumahan dan Kawasan Pemukiman, serta Kepmenpera nomor. 9 /KPTS/M/1995 tentang Pedoman Pengikatan Jual Beli Rumah dimana mengatur tentang kewajiban pengembang.

Berdasarkan hal-hal yang telah penulis uraikan pada bab-bab terdahulu maka dapat disampaikan beberapa saran sebagai masukan. Dalam pembuatan Pengikatan Jual Beli (PJB) antara pengembang dengan konsumen hendaknya memcantumkan segala hal tentang hak dan kewajiban para pihak, antara lain para pihak yang bertindak mewakili PT. Pratama Griya Makmur harus direktur mewakili perusahaan, pencantuman perihal denda-denda terhadap kedua belah pihak apabila lalai atau melakukan wanprestasi. Semua hal mengenai teknis perlu juga di masukkan kedalam isi PJB agar memberikan kepastian hukum akan hak-hak dan kewajiban kedua belah pihak jika terjadi perselisihan di kemudian hari. PJB harus mengacu kepada Kepempera Nomor Kepmenpera nomor 9/KPTS/M/1995 tentang Pedoman Pengikatan Jual Beli Rumah dan peraturan perundang-undangan. 


\section{DAFTAR KEPUSTAKAAN}

Amiruddin, dan Zainal Asikin, Pengantar Motode Penelitian Hukum, Jakarta: PT. Raja Grafindo Persada, 2004.

http:kulliaharsitektblogspot.com, diakses pada hari Selasa tanggal 20 Februari 2018.

https://pasamanbaratkab.bps.go.id, diakses pada hari Rabu tanggal 13 Juni 2018.

Kepmenpera Nomor 09/KPTS/M/1995 tentang Pedoman Pengikatan Jual Beli Rumah.

Mertokusumo, Sudikno, “Arti Penemuan Hukum”, Majalah Renvoi, Edisi tahun 1, No 12, 2004.

Situmorang, Victor M. dan An Cormentyana Sitanggang, Grosse Akta Dalam Pembuktian dan Eksekusi, Jakarta: Renika Cipta, 1993

Sofwan, Sri Soedewi Masjchun, Hukum Bangunan, Perjanjian Pemborongan Bangunan, Yogyakarta: Liberty, 1982.

Undang-undang Dasar Negara Republik Indonesia tahun 1945;

Undang-Undang Nomor 8 Tahun 1999 Tentang Perlindungan Konsumen;

Undang Undang Nomor 30 Tahun 2004 Tentang Jabatan Notaris;

Undang Undang Nomor 1 Tahun 2011 Tentang Perumahan dan Kasawan Pemukiman;

Undang Undang Nomor 5 Tahun 1999 Tentang Larangan Praktek Monopoli dan Persaingan Usaha;

Undang Undang Nomor 18 Tahun 1999 Tentang Jasa Konstruksi;

Undang-Undang Nomor 4 Tahun 2007 tentang Perseroan Terbatas 